\title{
FAZENDO POLÍTICA EM OUTROS CONGRESSOS: TRAMAS RELIGIOSAS, PRÁTICAS MIDIÁTICAS E A ESTÉTICA DA POLÍTICA NAS PERIFERIAS URBANAS DO RIO DE JANEIRO ${ }^{1}$
}

\section{Carly Barboza Machado}

Resumo: Tendo por base a etnografia realizada no Congresso Internacional de Missóes - CIM - organizado pelo Ministério Flordelis há mais de 10 anos no Rio de Janeiro, proponho-me a discutir a relação entre pentecostalismo, mídia e política, explorando as possibilidades de uma pesquisa em um evento religioso, e procurando assim priorizar, a partir deste recorte, as formaçóes e transformaçóes de campos religiosos e políticos. Articulado a uma antropologia de eventos, sugiro um debate acerca das escalas da ação política, e da formação e decomposição de alianças nestes contextos dinâmicos. Destaca-se ainda no presente artigo uma discussão sobre a estética da política no Brasil contemporâneo, partindo da centralidade da mídia pentecostal neste processo, e pensando em particular a mediação da música gospel no fazer da política nas periferias do Rio de Janeiro nos últimos anos.

Palavras-chave: Pentecostalismo; Mídia; Política; Música gospel.

THE MAKING OF POLITICS IN OTHER CONGRESSES: RELIGIOUS ENTANGLEMENTS, MEDIA PRACTICES AND THE AESTHETICS OF POLITICS IN THE URBAN PERIPHERIES OF RIO DE JANEIRO

Abstract: Based on an ethnography conducted at the Congresso Internacional de Missóes - CIM - organized by the Flordelis Ministry for over 10 years in Rio de Janeiro, I propose to discuss the relationship between pentecostalism, media and

${ }^{1}$ Como Citar: MACHADO, Carly Barboza. Fazendo política em outros Congressos: tramas religiosas e práticas midiáticas e a estética da política nas periferias urbanas do Rio de Janeiro. Debates do NER, Porto Alegre, v.2, n. 38, p. 19 - 59, 2020.

${ }^{2}$ Doutora em Ciências Sociais pelo Programa de Pós-Graduação em Ciências Sociais da UERJ. Professora do Departamento de Ciências Sociais e do Programa de Pós-Graduação em Ciências Sociais da Universidade Federal Rural do Rio de Janeiro, Brasil. E-mail: machado.carly@gmail.com. 
politics, exploring the possibilities of a research in a religious event as a way to prioritize formations and transformations of religious and political fields. Combined with an anthropology of events, I suggest a debate about the scales of political action, and the formation and decomposition of alliances in these dynamic contexts. The present article also intend to approach the discussion on the aesthetics of politics in contemporary Brazil based on the centrality of Pentecostal media in this process, and thinking in particular the mediation of gospel music in the making of politics in the peripheries of Rio de Janeiro in recent years.

Keywords: Pentecostalism; Politics; Media; Gospel music.

\section{INTRODUÇÃO}

Quando voltei meus interesses para o Ministério Flordelis ${ }^{3}$, em 2016, fui impactada pelo seu principal evento que à época já se realizava há mais de 10 anos: o Congresso Internacional de Missōes - CIM. Situado em São Gonçalo, o Congresso reunia anualmente um conjunto muito grande de pregadores e pregadoras, cantoras e cantores, e representantes de diversos grupos religiosos e políticos. Percebo hoje, 4 anos depois, que meus anos de pesquisa no CIM acompanharam o auge deste Congresso, e talvez por isso eu também tenha sido capturada pelas forças que ali se concentravam naquele momento.

Fui levada ao Ministério Flordelis por um mediador específico: Tonzão ${ }^{4}$, na época cantor de funk gospel (Paz, 2018), e recém-saído da igreja onde

\footnotetext{
${ }^{3}$ Projeto de pesquisa "Ministérios evangélicos e periferias fluminenses: religião, mídia, ação política e cultura no cotidiano das cidades da Região Metropolitana do Rio de Janeiro", coordenado por Carly Machado (Bolsa Produtividade CNPQ - Nível 2).

${ }^{4}$ Sobre a trajetória de Tonzão no funk gospel, ver a dissertaçâo de mestrado de Sthefanye Paz (PPGCS/UFRRJ, 2018), desenvolvida no âmbito do projeto de pesquisa "Ministérios evangélicos e periferias fluminenses: religiáo, mídia, ação política e cultura no cotidiano das cidades da Regiáo Metropolitana do Rio de Janeiro", coordenado por Carly Machado (Bolsa Produtividade CNPQ - Nível 2).
} 
eu fazia meu campo anterior (a Assembleia de Deus dos Últimos Dias - $\mathrm{ADUD}^{5}$ ). A inserção de Tonzão no Ministério Flordelis deslocou meu interesse para este novo campo de pesquisa, de certa forma em continuidade com minha pesquisa anterior: minha intenção era a de acompanhar um grupo religioso pentecostal com atuação sólida nas periferias urbanas do Rio de Janeiro, e com fortes frentes de ação midiática ${ }^{6}$. Procurando conhecer mais profundamente as particularidades desse novo campo, me aproximei da trajetória de Flordelis: pastora, mulher, negra, cantora gospel, pré-candidata à prefeitura de São Gonçalo em 2016, e com uma história, até então, permeada por acontecimentos de importante repercussão pública, que já haviam inclusive resultado na produção de um filme sobre sua vida.

Cheguei no Ministério Flordelis com minhas atençóes direcionadas ao seu principal evento anual, o Congresso Internacional de Missóes (CIM). Tonzão divulgara em suas redes sociais que se apresentaria no evento agendado para a semana do feriado de sete de setembro de 2016. Mesmo antes de colocar os pés na Cidade do Fogo - nome da sede do Ministério Flordelis - comecei a acompanhar o CIM a partir da dinâmica e dos fluxos de sua organização e montagem. E assim o foi de 2016 a 2018. Um desses fluxos se manifestava nas redes sociais através da confirmação dos convidados oficiais do evento, e da montagem gradual do panfleto digital de divulgação do

${ }^{5}$ Sobre a pesquisa na ADUD, ver Birman e Machado (2012); Machado (2017a); Machado (2017b).

${ }^{6} \mathrm{O}$ projeto de pesquisa "Ministérios evangélicos e periferias fluminenses: religião, mídia, ação política e cultura no cotidiano das cidades da Região Metropolitana do Rio de Janeiro" desenvolve-se no âmbito de dois grupos de pesquisa: Observatório Fluminense (UFRRJ) e Distúrbio (UERJ). As questóes analíticas que permeiam as conclusōes apresentadas neste artigo estão diretamente articuladas aos debates desenvolvidos nesses dois coletivos de pesquisa. Gostaria ainda de destacar a importância do grupo de estudos "É muita mistura" na construção desta pesquisa e deste artigo. Esse grupo formado por alunos, ex-alunos e queridos interlocutores foi constituído nos tempos de pandemia do ano de 2020, e tem sido desde então um espaço de acolhimento afetivo, acadêmico e intelectual para todas as ideias que ouso formular.

Debates do NER, Porto Alegre, ano 20, N. 38, P. I9-59, Ago./DeZ. 2020 
Congresso e de sua programaçáo. Ao longo das semanas que antecediam o evento, as atraçôes iam sendo anunciadas pelo Facebook e pelo Instagram, e o conjunto de cantores e palestrantes se avolumava. Às vésperas do Congresso, o panfleto digital já reunia quase uma centena de pessoas.

Outro movimento que se dava como parte da preparaçáo do CIM era a organização das caravanas vindas das mais diversas cidades do Rio de Janeiro, e algumas de fora do estado. Nos dias mais próximos ao evento, com a programaçáo confirmada, os anúncios das caravanas - grupos em modelo de excursão que se organizam para viabilizar o acesso ao CIM, incluindo transporte e hospedagem - performatizavam mais um plano do fluxo de pessoas que se movia na direção da Cidade do Fogo.

Quando tive acesso pela primeira vez à programaçáo completa do evento, comecei a entender a massiva presença dos convidados: com duraçáo de uma semana, a agenda previa dois cultos por dia. Aos sábados, domingos e no feriado, a quantidade de cultos chegava a três: um às $9 \mathrm{~h}$ da manhã, outro às $15 \mathrm{~h}$ e o último com início às $19 \mathrm{~h}$. $\mathrm{O}$ feriado, relembro, era o dia $07 \mathrm{de}$ setembro, data oficialmente referida no calendário nacional à "Independência do Brasil". Nos anos de 2016 a 2018 o CIM aconteceu sempre na semana deste feriado. Em alguns dias, os cultos da noite se encerravam perto de 1 da manhá. Daí a importância das caravanas, já que o acesso à Cidade do Fogo através de transporte público era bastante complicado, ainda mais para pessoas de outras cidades.

A preparação do CIM consistia anualmente no primeiro ato da performance de poder relacionada ao evento. A demonstração pelas mídias sociais da capacidade de captação de convidados para o Congresso era um aspecto central da mobilização realizada pelo Ministério Flordelis, liderado pela Pastora e cantora Flordelis e seu marido, o Pastor Anderson do Carmo. Os anúncios, dia após dia, atualizando a lista dos convidados confirmados, seguia a lógica da divulgação da line up de um grande festival que, neste

${ }^{7}$ Em sua análise da Marcha para Jesus, Sant'Ana (2017) também destaca a dinâmica das caravanas que conduzem ao evento.

Debates do NER, Porto Alegre, ano 20, N. 38, P. I9-59, Ago./Dez. 2020 
caso, demonstrava a capacidade de articulação deste Ministério com a mídia gospel, com as principais instituições evangélicas, prioritariamente pentecostais, e com mediadores importantes da política local e nacional.

$\mathrm{O}$ presente artigo tem por objetivo discutir a relação entre pentecostalismo, mídia e política a partir do Congresso Internacional de Missóes - CIM. Este trabalho pretende trazer contribuiçôes para debates acerca das escalas da ação política (da local à nacional) a partir do campo político pentecostal mobilizado pelo CIM, no Rio de Janeiro, e sua dinâmica de formação e decomposição de alianças. Pretendo, a partir desta reflexão, dialogar com o campo de estudos em religião e política, especialmente com os debates sobre o fazer político de grupos evangélicos a partir de suas práticas midiáticas (Freston, 2003; Machado, 2006; Birman, 2003), e do ponto de vista das periferias urbanas (Almeida e D’Andrea, 2004; Cunha, 2015; Mafra e Almeida, 2009; Teixeira, 2011; Birman, 2012).

A elaboração desta reflexão partiu das possibilidades de produção de conhecimento antropológico por meio desse tipo de evento - um Congresso - como alternativa às análises do campo religioso dentro de instituiçóes específicas. Este recorte procura priorizar as formações e transformações de redes e campos religiosos e políticos. Estas reflexôes remetem a leituras sobre performances (Peirano, 2002), e uma abordagem situada, sobre eventos, com o propósito de desenvolver uma análise dos atores em relação (Gluckman, apud Feldman-Bianco, 2010; Meinert e Kapferer, 2015). Destaco ainda, no âmbito deste artigo, a importância do diálogo com trabalhos acerca dos espaços e tempos da política no Brasil, que se incluem nesses diferentes eventos e festas (Chaves, 2000; Chaves, 2003; Teixeira e Chaves, 2004; Sant'Ana, 2017; Dullo, prelo).

Destaca-se, ainda nesta análise, uma discussão sobre a estética da política no Brasil contemporâneo partindo da centralidade da mídia pentecostal neste processo, pensando, em particular, a mediação da música gospel no fazer da política nas periferias do Rio de Janeiro nos últimos anos. Além dos autores que tratam da música gospel (Cunha, 2004; Jungblut, 2007; Paula, 2007; Pinheiro, 2007; Sant'Ana, 2013 e 2017; Bandeira, 2017; Oosterbaan, 
2015 e 2017) minhas questôes se relacionam com o campo de estudos de religião e mídia (Meyer e Pels, 2003, Meyer e Moors 2006, Meyer 2009, Meyer 2013; Stolow, 2013) e os desafios que se colocam para os campos da religiâo e da política a partir das mídias e das práticas de mediaçôes.

\section{\#CIM2016/2017/2018: OCUPAR A IGREJA, A RUA E AS MÍDIAS SOCIAIS}

Acompanhei o Congresso Internacional de Missōes - CIM - nos anos de 2016, 2017 e 2018. Nesses anos, no nível nacional, aconteceram o impeachment da presidente Dilma Rousseff, o governo de Michel Temer e a eleiçáo de Jair Bolsonaro. Ao mesmo tempo, nas ruas, aconteciam as "manifestaçôes" pró e contra Dilma e o PT, contra Temer, pró Lula/Haddad, e pró e contra Jair Bolsonaro. Nas mídias sociais tivemos o boom das hashtags: \#nãovaitergolpe, \#foradilma, \#foratemer, \#lulalivre, \#elenão, \#elesim, dentre outras. Simultaneamente, também nas ruas, aconteciam Marchas para Jesus (Sant'Ana, 2017) e diversos atos públicos mobilizados por atores do meio evangélico (Maurício Junior, 2019).

Outros eventos, no entanto, aconteciam entre a igreja e a rua, como o caso do CIM. Na rotina ordinária da Cidade do Fogo, seus cultos se davam no amplo galpão da igreja, com a presença majoritária de seus membros, em datas e horários pré-agendados. Durante o Congresso Internacional de Missóes o ato religioso se expandia em público, no espaço e no tempo. Abrindo-se a parede móvel do fundo do templo, prolongava-se o local da celebração ao longo do estacionamento da sede, triplicando seu tamanho. A arquitetura do templo já fora feita para se expandir. Além de tomar toda a Cidade do Fogo (incluindo uma área separada para a divulgação dos parceiros e venda de produtos), o CIM invadia a rua, onde moradores e comerciantes da regiáo montavam suas próprias barraquinhas para venda de comidas e bebidas, e também se ocupavam por providenciar locais para o estacionamento dos carros dos participantes da grande festa anual. 
A pesquisa no CIM foi uma experiência fundamental para a compreensão da relevância das análises sobre eventos de uma maneira bastante interessante. $\mathrm{O}$ CIM era um evento anual. Diferente de outros eventos que são únicos, singulares, um acontecimento particular, o CIM possibilitou, ao mesmo tempo, uma pesquisa sobre eventos e uma análise de processo, dada sua historicidade e a minha possibilidade de acompanhá-lo por 3 anos.

Meinert e Kapferer (2015), em sua coletânea sobre uma antropologia de eventos, apresentam uma rica discussão a respeito dos aspectos metodológicos e teóricos deste modo de fazer pesquisa. Partem das questóes colocadas pela Escola de Manchester e, indo para além dela, tocam principalmente em debates pós-estruturalistas acerca da ideia de "sociedade" que intentam superar os termos estruturalistas que se situam na base dos trabalhos de Gluckman e Mitchell. Os autores aprofundam reflexôes sobre abordagens metodológicas que tomam eventos como forças singulares nas quais dimensóes críticas da existência sócio cultural apresentam potenciais novos da formação processual das realidades sócio culturais. Abordar eventos impóe uma análise que trate de espaço e tempo, articulações entre organização e significado, e de relaçóes qualificadas entre micro e macrocosmos.

As pesquisas de Chaves (2000) e Sant'Ana (2017), sobre a Marcha dos Sem Terra, e a Marcha para Jesus, respectivamente, e o artigo de Dullo (no prelo) sobre as manifestaçóes de rua de 2013 são trabalhos fundamentais para a construção desta abordagem do CIM. Em todos os casos, coloca-se em questão a dimensão espaço - temporal de eventos do tipo, e como a partir destes se formam espaços e tempos da política (Teixeira e Chaves, 2004) ou "political seasons" (Das apud Dullo, prelo). Outro aspecto relevante é o seu caráter performativo, a dinâmica dos atores, as hierarquias, os movimentos, os silêncios, as pausas, as açóes. Uma leitura que enfatiza o "feito" e não apenas o "dito" em atos religiosos e políticos (Peirano, 2002). Acompanhar eventos anuais aponta, ainda, para a observação de continuidades e rupturas, implicando em uma análise de processos sociais, situados e fluidos. 
Pensando sobre a dimensão festiva do CIM enquanto modo de fazer política, me valho das questóes colocadas por Chaves (2003) sobre como a festa faz política.

Dar relevância teórica ao fato de que a festa apresenta uma qualidade política representa uma mudança de rota e uma alteraçáo dos parâmetros nos quais é usualmente pensado o fenômeno da política. Implica reconhecer que os padróes estabelecidos na configuração moderna de valores são ineficientes para entender, porque incapazes de abarcar, a totalidade das formas políticas entre nós operantes (Chaves, 2003, p. 21).

Para pensar festa e política, Chaves fala sobre como o espaço/tempo das festas formam práticas públicas nas quais se realiza um diálogo mais ou menos explícito entre população e políticos, se mobilizam manifestações de poder, e se conforma um espaço concreto onde a política é vivida e percebida como relação particular entre pessoas. As "festas da política" que articulam práticas religiosas católicas e o fazer da política são mais conhecidas, dados trabalhos antropológicos sobre o tema. Pretendo aqui abordar mais detalhadamente a dinâmica e os atores envolvidos em uma festa da política a partir do meio pentecostal.

Contemporaneamente, o espaço/tempo de eventos e festas se expandem cada vez mais através das mídias. O CIM, em todas as ediçóes que acompanhei, foi bastante difundido a partir de suas redes sociais: os cultos eram transmitidos online via Youtube, e fotos e vídeos eram publicados no Facebook e no Instagram pela organização do evento. Os cantores, pregadores e a audiência do CIM participavam dos cultos também postando seus conteúdos em suas mídias sociais, fazendo fotos, lives e stories, e usando as hashtags sugeridas pelos organizadores: \#CIM2016, \#CIM2017, \#CIM2018. Na divulgação do evento de 2016, a informação sobre o número de participantes era a seguinte: "mais de 100 mil pessoas presentes; mais de um milhão de acessos em 42 países".

A intensificação do tempo se realizava pela organização de dois a três cultos por dia durante o Congresso. Uma semana parecia durar um mês, 
dada a quantidade de eventos e pessoas circulando pela Cidade do Fogo. A difusão pelas mídias sociais operava essa ampliação, tornando possível participar de uma temporalidade multiplicada, visto que os conteúdos online podiam ser assistidos e comentados para além do tempo real dos acontecimentos.

A prática de multiplicação dos eventos a partir da ocupação ampliada do espaço e do tempo através da difusão de conteúdos pelas mídias sociais é parte das mais variadas formas de ação coletiva no Brasil e no mundo atualmente. As mídias digitais expandem efeitos de acontecimentos locais e multiplicam práticas em formatos extremamente plurais. Isso se aplica tanto ao campo da política, da cultura, do entretenimento, quanto da religiáo, e o CIM agrega todos estes elementos. Um evento de alta densidade que, ao mesmo tempo, opera a partir de uma alta concentração de elementos estéticos, midiáticos, tecnológicos e sensoriais, todos altamente imersivos e que produzem uma intensa dispersão de seus efeitos.

Appadurai (2005) ressalta a relevância da "paisagem midiática" para se pensar a vida moderna, destacando a importância de tratar do trabalho da imaginação, mediada pelos meios de comunicação, enquanto parte do cotidiano mental das pessoas comuns em todas as sociedades. As mídias, reforça Appadurai, compreendidas por tantos como o "ópio das massas", têm sido operadas, alteradas, reproduzidas pelos sujeitos, e produzido seletividade, ironia, resistência, ódio, humor, e outras tantas açóes que se dão com elas e a partir delas.

A relação entre evangélicos e política no Brasil vem sendo amplamente discutida há alguns anos e por diferentes autores. Desde os estudos mais clássicos, a percepção da presença e da importância política da mídia já era abordada por pesquisadores do campo. Em seu trabalho de 1993, "Brother votes for Brother", Paul Freston abre seu texto com a cena de um evento 
musical no qual candidaturas políticas estavam sendo apresentadas ao público evangélico. Assim termina o autor sua descriçāo do referido evento:

As the candidate leaves, the elderly pastor preaches a short sermon and the music group begins to play. Strong ruthym, deafening volume, the young people clapping and swaying. What is all this? It is a Pentecostal political relly - unthinkable a few years back, and enough to make many a Pentecostal pioneer turn in his grave (Freston, 1993, p. 66) ${ }^{8}$

Desde então, as práticas midiáticas do campo evangélico têm sido acompanhadas por Paul Freston em suas reflexóes. Machado (2006), em sua análise das eleiçóes do ano de 2000 no município do Rio de Janeiro, se mostra atenta ao que se dá na mídia durante a campanha eleitoral. Em "De olho na tela e no púlpito", Machado analisa como a moralidade evangélica é mobilizada na campanha através da TV e da mídia impressa. Muitos estudos sobre o tema no final dos anos 90 e início dos anos 2000 abordaram a frente midiática da Igreja Universal do Reino de Deus (IURD) enquanto importante campo de pesquisa e debates.

Birman (2003), em seu texto intitulado "Imagens religiosas e projetos para o Futuro", ao tratar da relação da IURD com o espaço público, afirmava que:

A presença dessa religiosidade espetacularizada na mídia cresce continuamente e tem resultado numa percepçáo nova e generalizada sobre "quem somos nós", "os brasileiros", historicamente considerados em narrativas que privilegiam a nossa catolicidade essencial. A paulatina inclusão desse grupo que se exibe como um "grande grupo" exterior à imagem nacional dominante, vem, pois,

8 "Quando o candidato sai, o pastor mais velho prega um pequeno sermão e o grupo musical começa a tocar. Ritmo forte, um volume estonteante, a juventude batendo palmas e se remexendo. O que é tudo isso? É uma realidade política pentecostal - impensável há alguns anos atrás, e suficiente para fazer muitos pioneiros pentecostais revirarem em seus túmulos" (Freston, 1993, p. 66 - tradução da autora).

Debates do NER, Porto Alegre, ano 20, N. 38, P. 19-59, Ago./Dez. 2020 
alterando a consciência religiosa do país e o imaginário da nação (Birman, 2003, p. 236)

As reflexôes de Birman perseguem o tema da relação entre evangélicos e a mídia, e um dos objetos tratados pela autora é uma cerimônia, um espetáculo da IURD denominado "Fogueira de Israel".

Neste circuito vai se produzindo conexóes progressivas entre as atividades rituais 'locais' e outras que saem das igrejas, para ocuparem áreas públicas, como estádios de futebol e que 'viajam' pelo mundo até alcançarem seu destino final, em rituais realizados por bispos da Igreja, a serem transmitidos pela mídia (Birman, 2003, p. 243).

Destaco os trabalhos de Freston, Machado e Birman para enfatizar o fato de que as reflexôes aqui desenvolvidas que tratam da relação entre religião e política, e que têm como ênfase o aspecto midiático desta relação, se encontram em continuidade com as questôes colocadas há mais de duas décadas por este campo de estudos no Brasil. A partir dessas referências e orientaçóes persigo tais problemas e procuro aprofundar e atualizar temas para reflexão.

\section{"EU SOU CANELA DE FOGO, RETETÉ DE JEOVÁ”}

Eu sou canela de fogo / Reteté de Jeová Estou nadando no azeite / Nấo consigo parar

Tô envolvido na glória / Tô envolvido no manto Estou andando em brasas eu náo estou suportando

O rolo está descendo enchendo este lugar Tem labaredas de fogo, em todo, em todo lugar

É labareda, é labareda de fogo / É labareda, é labareda de fogo 
É fogo santo, fogo puro, é por isso que eu não mudo / Não paro de adorar

(Canela de fogo. Intérprete: Flordelis) $^{9}$

O Ministério Flordelis que organiza o CIM é um ministério pentecostal que confirma sua identidade "de fogo ${ }^{10}$ " através de diferentes formas estéticas: no nome de sua sede (Cidade do Fogo), na logomarca do Ministério (uma composição das imagens superpostas de uma cruz, uma Flor de $\mathrm{Lis}^{11} \mathrm{e}$ uma labareda de fogo), nas músicas entoadas pela congregação (os "corinhos de fogo"), e na frequente projeção nos telóes da igreja de imagens de fogo, compostas por jogos de luzes vermelhas, amarelas e laranjas. Todos estes elementos combinados tornam o saláo da Cidade do Fogo um caldeiráo pentecostal, repleto de pessoas cantando, entoando oraçóes, Glórias e Aleluias, e pleno de abundantes movimentos corporais que acompanham oraçóes e cânticos. Flordelis conclama o público do CIM a fazer muito barulho porque, como afirma repetidamente, "o povo pentecostal é um povo barulhento"12.

A história de Flordelis e Anderson do Carmo foi publicamente formulada e apresentada como uma história de transformação e superaçáo, marcada por uma característica central e peculiar: o casal tinha 55 filhos -4 biológicos e

${ }^{9}$ EU SOU CANELA DE FOGO - FLORDELIS FT. LUAN SANTOS (DVD FLORDELIS). Publicado pelo canal Flordelis [S.I.:s.n.] 2018. 1 video (4:04 min). Disponível em https://www.youtube.com/watch?v=K0JD8TPumQQ Acesso em 31 Agosto 2020.

${ }^{10} \mathrm{O}$ Pentecostalismo, em sua genealogia, apresenta diversos elementos de fogo: o batismo no Espírito Santo ocorrido no Pentecostes (uma de suas características centrais) é nomeado como Batismo de fogo, assim como as línguas nele faladas: as línguas de fogo.

${ }^{11}$ Lírio frequentemente utilizado em brasôes e escudos que representam a monarquia francesa.

${ }^{12}$ Projetos que mobilizam uma forte ação pública pentecostal operam em geral a partir de dois principais conjuntos de referências: a ideia de batalha espiritual (Mariz, 1999) e uma teologia do domínio (Sant'Ana, 2017). O Ministério Flordelis traz características de ambos. Sobre a ideia de "povo", processos de minoritização a partir do campo evangélico, e o lugar da mídia nas estratégias de abertura no campo pentecostal, ver Burity (2016).

Debates do NER, Porto Alegre, ano 20, N. 38, P. 19-59, Ago./Dez. 2020 
51 adotados. Os 51 filhos adotados por Flordelis tinham trajetórias associadas ao mundo do crime e da violência, assim como a própria pastora, mulher, negra, nascida e criada na favela do Jacarezinho, Zona Norte da cidade do Rio de Janeiro. A proteção de seus filhos era o eixo da narrativa da vida de Flordelis: por eles ela conta ter enfrentado bandidos e juízes que resistiam em lhe conceder a guarda das crianças ${ }^{13}$.

Flordelis já estampou manchetes de jornal, sendo acusada de "sequestradora” por manter sob seu teto crianças que não eram oficialmente seus filhos. Sua batalha judicial pela guarda dessas crianças fez com que Flordelis fosse apresentada pela mídia de massa, na TV e em jornais, ora como louca, ora como uma heroína. Em 2009 sua história virou um filme: "Flordelis - Basta uma palavra para mudar". O projeto conta com a participação de atores famosos que atuaram sem cachê e liberaram toda a renda do filme para Flordelis e seus filhos.

Nos anos 90 Flordelis já atuava como missionária nas favelas cariocas, mas o ano oficial de Criação da Comunidade Evangélica Ministério Flordelis é 1999. Quando da fundação do Ministério, em um bairro do subúrbio da cidade do Rio, já estava casada com Anderson do Carmo, e seus filhos mais velhos já atuavam no projeto. Em 2002 o Ministério deslocou-se para a cidade de São Gonçalo, na Região Metropolitana do Rio de Janeiro onde aconteceu o primeiro CIM, que desde então teve mais de 10 ediçôes.

O CIM inicialmente tinha por objetivo oficial arrecadar fundos que sustentassem os projetos sociais dirigidos por Flordelis. Além das doaçôes sob a forma de ofertas, o Congresso contava com barracas de comida organizadas pelos diferentes grupos da igreja (jovens, mulheres etc.), onde também eram vendidos os discos e livros de Flordelis.

${ }^{13}$ BARBOSA, CAIO. A MÃE DE 55 FILHOS. Site da Revista Marie Claire [S.I.:s.n.] 2012. Disponível em:. http://revistamarieclaire.globo.com/Revista/Common/0,,EMI319129-17737,00-A+MAE+DE+FILHOS.html Acesso em 31 Ago 2020

Debates do NER, Porto Alegre, ano 20, N. 38, P. I9-59, Ago./Dez. 2020 
Jesus entrou aqui, não veio para brincar

Veio para decidir histórias vão mudar Deus vai entrar na tua vida, vai restaurar o teu lar Sabe aquela enfermidade? Hoje o meu Deus vai curar Vai libertar o teu filho das drogas e da prisáo Sabe aquele teu marido? Vai marchar com o varão Sabe aquela tua filha que vive na perdição Ela vai virar a líder do grupo de oração Sabe aquela feiticeira que tentou contra você Deus vai entrar na peleja ela vai é se converter

A fórmula central da história de Flordelis é sua forte ênfase na possibilidade de Deus transformar vidas a partir da instituiçáo familiar. Os riscos da vida nas periferias são precisamente delineados na letra do cântico aqui citado, por gênero e geração. São as doenças que podem atingir a todos, a vida displicente do homem adulto "mau marido", o risco do jovem rapaz tornar-se um bandido e da jovem menina tornar-se uma "perdida", e mal falada. A soluçáo para todos estes problemas é a família conduzida com pulso forte pelo casal que lhe dá origem, especialmente pela máe, representada pela imagem de Flordelis. Muitos ministérios pentecostais se organizam como ministérios de "casais" nos quais a mulher, cantora, apesar de protagonista do ministério, não conduz o projeto sozinha, sendo usualmente associada ao Pastor (seu marido). Casos em que estes casais se divorciaram redundaram em escândalos no meio evangélico e levaram ao fim dos ministérios conduzidos pelo casal, especialmente daqueles nos quais a mulher era o destaque ${ }^{14}$.

O Ministério Flordelis, assim como o evento do CIM, mobilizam um protagonismo feminino típico de certos contextos de práticas pentecostais,

${ }^{14}$ TRAIÇÓES E ATÉ TRIÂNGULO AMOROSO: RELEMBRE AS POLÊMICAS QUE CHOCARAM O MUNDO GOSPEL. Redação IBahia [S.I.:s.n.] 2016. Disponível em: https://www.ibahia.com/detalhe/noticia/traicoes-e-ate-triangulo-amoroso-relembre-as-polemicas-que-chocaram-o-mundo-gospel/ Acesso em 31 Agosto 2020. 
e que merecem a devida atenção nas pesquisas sobre o tema, inclusive no que diz respeito à formação de mulheres, mulheres negras, cantoras gospel, como quadros da política no campo evangélico. A dimensão interseccional que atravessa as discussões em torno da figura de Flordelis (gênero ${ }^{15}$, raça $^{16}$, religião e território), apesar de não se apresentar integral e devidamente articulada neste artigo, é, sem sombra de dúvidas, fundamental para o debate que aqui se coloca. Centro-me neste texto, dados os seus limites, nos temas com os quais dialogo há mais tempo: religião, política, mídia e periferia. Pretendo, se eu for capaz e se esta pretensão for viável, dedicar-me aos temas de gênero e raça em trabalhos futuros e, com sorte, espero desenvolvê-los junto a parcerias qualificadas.

Partindo da lógica de expansão da "família Flordelis" para além de seus 55 filhos, o primeiro alvo deste Ministério foi a cidade, e a "proteção dos jovens vulneráveis". São Gonçalo é o segundo maior município do estado do Rio de Janeiro, com uma população estimada de mais de 1 milhão de pessoas. De acordo com Pinho (2006):

${ }^{15}$ Patrícia Birman (1996) aponta para os efeitos combinados da constituição mais forte de um "personagem evangélico" mais mundano nos anos 2000, ou seja, não necessariamente ligado a uma igreja, e a "presença maciça de mulheres" neste processo. Em seu texto, Birman discute o papel de mediadoras destas mulheres que, em sua leitura, criam campos de continuidade entre "crentes e não crentes”. Maria das Dores Machado (2005) discute há quase duas décadas a relação entre pentecostalismo e gênero, analisando processos de "individualização" e formação da autonomia moral em mulheres do meio evangélico, assim como o fortalecimento de suas participaçóes públicas e políticas a partir de práticas no campo pentecostal. Teixeira (2016) desenvolve uma importante discussão sobre a "mulher universal" e seu processo de subjetivação no âmbito da teologia da prosperidade da Igreja Universal do Reino de Deus

${ }^{16}$ Desde as reflexôes de John Burdick (2002), uma das primeiras sobre a relação entre o pentecostalismo e a identidade negra no Brasil ("mistura possível?”), muito tem sido discutido e ainda há a ser pensado sobre este tema. Destaco aqui as reflexóes de Contins (2004) sobre pentecostais negros no Brasil e nos EUA, e o debate apresentado por Reina (2017) sobre "os desafios e as possibilidades de ser negro na igreja evangélica".

Debates do NER, Porto Alegre, ano 20, N. 38, P. I9-59, Ago./DeZ. 2020 
O crescimento de São Gonçalo deve-se, naturalmente, à dinâmica da metrópole carioca, constituindo-se a partir dos anos 1940, diante do elevado processo de urbanização, numa aglomeração urbana, reservatório de mão-de-obra barata, notadamente formada por emigrantes nordestinos. Nos anos 1950, a cidade chegou a ser considerada polo industrial, tendo também expressiva concentração de fazendas dedicadas à citricultura. A partir dos anos 1980, como ocorreu com o restante do país, a recessão econômica e a desindustrialização tiveram seus efeitos sentidos na cidade. Considerada "periferia consolidada", a cidade de São Gonçalo inscreve-se na teia de relaçóes metropolitanas como uma regiáo de privação relativa ou pobreza (Pinho, 2006, p. 171).

A partir de São Gonçalo, e sua realidade ao mesmo tempo local e transversal, o CIM se comunica com todas as periferias brasileiras em um jogo de escalas. A relação entre práticas pentecostais e as periferias urbanas brasileiras vem sendo tratada há alguns anos e por diferentes perspectivas ${ }^{17}$. Birman, em artigo de 2012, discute as relaçóes entre o religioso e o secular na composição do dispositivo da violência enquanto modelo ordenador da cidade.

As formas de habitar e de circular na cidade, bem como as disposiçóes subjetivas relativas às divisóes de seus espaços, foram paulatinamente se alterando, marcadas por novas modalidades de intervenção e de reelaboração de suas práticas. A categoria "violência" aumentou a sua abrangência e seus sentidos e se impôs como uma das justificativas centrais para reordenações necessárias

${ }^{17} \mathrm{O}$ amplo e diverso campo de estudos sobre o pentecostalismo nas cidades e nas periferias urbanas promoveu importantes estudos para estimular reflexôes sobre a relação entre religiâo, favela e cidade (Mafra, 2003; Almeida e D’Andrea, 2004; Mafra e Almeida, 2009); pentecostalismo, crime e violência (Cunha, 2015; Teixeira, 2011 ; Mesquita, 2013; Galdeano, 2013; Machado, 2014); sobre o pentecostalismo no âmbito das políticas de segurança pública praticadas no Rio de Janeiro (Birman, 2012; Machado, 2017a e 2017b); sobre o tema da relação entre práticas evangélicas e o campo da assistência (Scheliga, 2010; Rosas, 2013); e a relaçáo entre práticas artísticas pentecostais e a cultura das periferias (Pinheiro 2007; Pinheiro e Farias, 2019; Oosterbaan, 2015; Machado, 2020). 
dos espaços da cidade, desdobrando-se em políticas de repressão, de controle, de vigilância e também de medidas sócio-morais dos sujeitos que seriam seus alvos preferenciais. As mediaçóes promovidas pelos atores religiosos no tratamento do "problema da violência" se desenvolveram ao longo desse processo e integraram os debates e também alguns dos dispositivos engendrados para governar a cidade, seus conflitos e suas populações. (Birman, 2012, p. 211)

As práticas do Ministério Flordelis apresentam um amplo conjunto de açôes que possibilitam debates acerca da relação entre pentecostalismo e desigualdade social, conflitos urbanos, crime e gestão da violência, projetos de ordem, e as práticas de governança nas periferias. Mas proponho, para os fins deste artigo, e com ênfase no Congresso Internacional de Missóes - CIM, uma discussão acerca da formação de redes e práticas políticas pentecostais situadas nas periferias e mobilizada partir de seus territórios. Analisando os encontros, consensos e dissensos acompanhados no CIM, pretendo descrever mediadores e mediaçóes da articulação interescalar entre projetos religiosos e políticos locais e nacionais, a partir deste território periférico em particular, e junto às suas lideranças religiosas.

\section{“A IGREJA ESTÁ DE PÉ EM TEMPOS DE CRISE”}

A igreja está de pé, mais forte do que nunca está de pé $\mathrm{Na}$ luta está orando, na prova adorando Mesmo perseguida ela vai rompendo em fé A igreja está de pé, mais forte do que nunca está de pé, vai vencendo as batalhas Pisando na serpente, pregando a palavra, ela vai rompendo em fé A igreja está de pé, a igreja do senhor está de pé Vencendo este mundo triunfando sobre o inferno, erguendo sua bandeira $^{18}$

${ }^{18}$ A IGREJA ESTÁ DE PÉ. Publicado pelo canal Flordelis [S.I.:s.n.] 2018. 1 video (4:41 min). Disponível em https://www.youtube.com/watch?v=dFV2J62g4Tc Acesso em 
O CIM contava com a participação de diversos tipos de convidados: cantores e cantoras, pregadores e pregadoras locais que atuavam no cotidiano da igreja, representantes de alguns dos Ministérios mais conhecidos do estado do Rio de Janeiro, e grandes nomes nacionais. Nos anos de 2016, 2017 e 2018, quando a ideia de "crise" dominava a cena política nacional, o CIM foi realizado em sua plena potência, confirmando a tese que deu título ao CIM 2016, e também tema de uma das músicas de Flordelis: "A igreja está de pé em tempos de crise”.

Congressos, como o CIM, operam no jogo de escalas entre o local e o nacional, e produzem efeitos muito consistentes de proximidade, próprios ao fazer da política eleitoral. Revel (1996, p. 14) vê no princípio da variação de escala um recurso fecundo por possibilitar que se construam objetos complexos e, portanto, que se leve em consideração a estrutura "folheada" do social. Pensar em escalas é pensar sobre os engendramentos entre o micro e o macro, e são amplos os debates sobre qual destas dimensões tem privilégio sobre a outra (idem). Vainer (2006) discute a questão da "escala da agência" e, particularmente, a "escala da ação política”. Complexificando a relação "micro" e "macro", Vainer afirma que as escalas não estão dadas, nem são fixas, nem podem ser reificadas. "Antes, devem ser trazidas para o terreno social incerto e móvel, daquilo que está em disputa” (p. 17).

escalas não são apenas socialmente construídas ou engendradas, como também, e sobretudo, estão permanentemente em questão, campo e objeto de disputas e confrontos entre diferentes agentes que propóem diferentes escalas e em diferentes escalas se dispóem - seja para conservar seja para transformar o mundo e as escalas que o organizam (Veiner, 2006, p. 17).

O CIM era um momento crucial da articulação entre o Ministério Flordelis e suas práticas locais com projetos religiosos e políticos que atuavam no âmbito nacional. Este é o caso do Pastor Silas Malafaia, representado no

24 Nov 2020.

Debates do NER, Porto Alegre, ano 20, N. 38, P. I9-59, Ago./Dez. 2020 
CIM 2016 por sua nora, a cantora Rachel Malafaia, e também do Pastor Marco Feliciano, presente nos CIM 2016 e 2017, e que nas duas situações evidenciou sua fidelidade ao Ministério Flordelis, relembrando sua participação contínua no evento há mais de 10 anos.

Dentre os inúmeros grupos religiosos que mandavam seus representantes ao CIM, sejam cantores ou preletores, destaco ainda a Igreja Batista da Lagoinha, o Ministério Apascentar, a própria Igreja Universal do Reino de Deus (em menor escala), dentre outros. Uma importante personalidade de alcance nacional presente no CIM em todos os anos aqui tratados foi a cantora e pastora Fernanda Brum. Fernanda Brum associa à sua carreira de cantora um conjunto de açóes sociais e uma abordagem à questão da mulher evangélica, particularmente quanto ao problema da violência doméstica. Há alguns anos Fernanda Brum realiza um grande congresso por ela definido como "transcultural e interdenominacional" voltado para o público feminino. A intenção do evento, em sua apresentação, é convocar mulheres dispostas a compreender o chamado de Deus, e despertar uma geração para viver um "novo tempo". Tal como o CIM, o Congresso "Profetizando às Mulheres" (analisado por Bezerra, 2018) reúne um grande conjunto de mediadores de campos políticos e religiosos, nacionais e internacionais.

Fernanda Brum, assim como Flordelis, faz parte do cast de artistas da gravadora MK Music. A MK Music e a Rádio 93 FM são agências midiáticas que combinam vários dos projetos que se encontram no CIM e, mais do que isso, que servem de eixo econômico de articulação do evento. Completando 30 anos em 2017, a MK Music se apresenta como uma face da "profissionalização" da música gospel no Brasil. É conduzida por Marina de Oliveira, cantora gospel e filha do senador pelo PSD (Partido Social Democrático), Arolde de Oliveira. Em todas as três edições do CIM em que estive presente, a MK Music teve um grande stand de venda de seus produtos. Também a Rádio 93 FM transmitia parte de seus programas da sede da Cidade do Fogo, e realizava entrevistas ao vivo durante o Congresso. O estúdio da rádio ficava em local central e visível durante todo o evento, 
com paredes de vidro que permitiam aos participantes acompanharem tudo que se passava lá dentro.

A carreira política de Arolde de Oliveira, dono da gravadora e da rádio, é integrada à sua carreira na mídia gospel, desde a criação da Rádio El Shaday em 1992 (atualmente Rádio 93 FM). Arolde participou nos anos 90 das iniciativas de privatização do setor de telecomunicaçóes no Brasil. Nos anos 2000 foi secretário de transportes da cidade do Rio no governo Cesar Maia, ficando 6 anos no cargo. Em 2014 venceu pela nona vez consecutiva a eleição para deputado federal, do Rio de Janeiro. Em 2018, elegeu-se senador pelo mesmo estado.

Nas eleições municipais de 2016, a Pastora Flordelis foi pré-candidata à prefeitura de São Gonçalo. A formação de alianças entre os partidos no processo de definição de candidaturas no município fez com que Flordelis retirasse sua candidatura, em apoio a outro candidato da coligaçáo de seu partido. Um de seus filhos, Misael, foi candidato a vereador de São Gonçalo. Seu nome na candidatura era "Misael da Flordelis", e seu lema "Vou dar a volta por cima”, título e refrão de um dos hits gospel de sua mãe. Em 2016 o Ministério Flordelis possuía um candidato a vereador em cada cidade onde tinha uma igreja (São Gonçalo, Niterói, Maricá e Itaboraí). Misael foi eleito em São Gonçalo.

Em 2018, Flordelis foi pré-candidata à deputada estadual no Rio de Janeiro pelo PSD (Partido Social Democrático), partido de Arolde de Oliveira, e o teve como seu padrinho político. Ao confirmar sua candidatura, Flordelis concorreu não à deputada estadual, mas sim à deputada federal pelo partido, ocupando o espaço da candidatura de Arolde que se projetou ao senado. Foi eleita como a quinta deputada federal mais votada no Rio de Janeiro no âmbito geral da eleição, e a mulher mais votada no estado, com quase duzentos mil votos.

A dinâmica político-religiosa que explica o Ministério Flordelis se apoia em um conglomerado denso formado por instituiçóes religiosas, do mercado e político partidárias, sendo estas aqui representadas pelo próprio Ministério e suas parcerias religiosas, a gravadora MK Music, e o partido 
de Arolde de Oliveira, no caso de 2018, o PSD. Em sua pesquisa sobre a Marcha para Jesus, Sant'Ana (2017) analisa em profundidade este campo de poderes religiosos, econômicos e políticos do Rio de Janeiro, apresentando outros atores, além dos aqui citados. Com esta fórmula, a igreja se manteve de pé em tempos de crise, e destes saiu, incialmente, fortalecida.

Parti de um projeto sobre Ministérios ${ }^{19}$, e cheguei aqui tendo como um dos principais resultados desta pesquisa a reflexão sobre Congressos. Ministérios e Congressos são categorias do mundo religioso e do mundo político. Alguns grupos se definem como ministérios hoje no cenário evangélico. Apesar da ideia de ministérios já existir há alguns anos dentro das igrejas protestantes, o uso que dá título ao coletivo religioso como um todo me parece oferecer algo sobre o que pensar.

Ministérios costumam ser, mais usualmente, modos de definir campos específicos de atuação e missão dentro de uma igreja: ministério de louvor, de crianças, de jovens, de mulheres, de assistência social, dentre outros. Outro uso frequente da ideia de ministério é aquele referido à relação entre sede e filial: Assembleia de Deus "X” - "Ministério Madureira”, ou seja, identifica uma igreja que se apresenta como filial, ou uma congregação missionária de uma Igreja maior. Um último modo de utilização, é como uma missão pessoal: o meu ministério, ou seja, a ação para a qual o sujeito se dedica pessoalmente.

No caso do Ministério Flordelis, como de outros, o projeto missionário passa a dar sentido à toda iniciativa, e também ao seu nome. Não existe uma igreja que dá origem ao Ministério. A ação religiosa é o Ministério, e estes assim se nomeiam. Ministério Apascentar, Ministério Casa de Oração, dentre outros. A particularidade do caso de Flordelis é o fato de seu nome dar título ao Ministério. Deriva-se daí algumas análises interligadas: seu ministério é a expansão de um ministério pessoal (cuidar de jovens), de louvor (carreira

${ }^{19}$ Projeto de pesquisa: Ministérios evangélicos e periferias fluminenses: religião, mídia, ação política e cultura no cotidiano das cidades da Região Metropolitana do Rio de Janeiro, coordenado por Carly Machado. Bolsa Produtividade CNPQ - Nível 2.

Debates do NER, Porto Alegre, ano 20, N. 38, P. I9-59, Ago./Dez. 2020 
musical) e sua fama (presença midiática). Esta última, particularmente, adiciona um aspecto relevante de visibilidade ao Ministério Flordelis.

Tentando refletir sobre o assunto, penso hoje que ministérios são iniciativas caracterizadas por suas missóes, seus projetos, seus planos de futuro. Depois de, por algum tempo, tentar fazer da ideia de ministério uma possível categoria analítica, arrisco-me a dizer que aprendi com os "ministérios evangélicos", ou seja, com estes grupos religiosos que se apresentam como “ministérios", que uma de suas principais características é a dimensão expansiva no tempo e no espaço. Eles não cabem apenas em suas comunidades religiosas e nas suas rotinas: apresentam como característica principal projetos voltados para a vida no mundo, na cidade, nas casas, nas famílias, nas ruas, e por isso nos ajudam a pensar a relação entre o religioso, o ordinário e o espaço público. Além disso, são projetos: movidos por planos de futuro, não apenas pelo que acontece no presente. Nesta dinâmica expansiva e multiplicadora, ministérios são instituiçôes dinâmicas, mutáveis, instáveis, e mobilizadoras de uma ampla ação midiática e de comunicação. O "templo" não é necessariamente seu lócus mais potente, mas seus eventos e suas mídias, através dos quais se expandem ${ }^{20}$.

No caso particular do Ministério Flordelis, acompanhar seu Congresso anual me permitiu acompanhar processos de formação e desengajamento de alianças religiosas, midiáticas, territoriais e políticas. Congressos religiosos como o CIM são momentos de encontros entre atores políticos, e desses com audiências que podem, a partir daí, formar comunidades religiosas ou campos políticos, bem como outras formas de coletividades, mais ou menos duradouras.

${ }^{20}$ Destaco aqui duas pesquisas que me ajudam a pensar este tema. A dissertação de mestrado de Jamille Bezerra (2008, UFRRJ) sobre o Ministério Profetizando às Naçóes com foco etnográfico no Congresso Profetizando às Mulheres, ambos liderados pela cantora gospel Fernanda Brum. E a tese de doutorado em andamento de Lorena Mochel (PPGAS/MN) sobre um ministério evangélico em um grupo de WhatsApp. 
A pesquisa no CIM e sobre o CIM permite análises sobre uma ampla variedade de temas em um complexo jogo de escalas. Escolhi, para os fins deste artigo, aprofundar uma análise a partir da música gospel, e seu lugar na fabricação da política nas periferias urbanas do Rio de Janeiro. E é a este foco que me dedico nas próximas seções.

\section{"A VOLTA POR CIMA"}

Quem impedirá o agir de Deus? Eu vou dar a volta por cima Ele cumpre o que prometeu. Eu vou dar a volta por cima O que passou, passou, chega de chorar! Eu vou dar a volta por cima Tudo que eu vivi, foi uma liçáo. Eu vou dar a volta por cima

Vai virar, vai virar A página da minha história meu Deus vai virar Vai virar, vai virar A página da minha história meu Deus vai virar ${ }^{21}$

Como visto nas seçôes anteriores, a carreira política de Flordelis se consolidou a partir de um importante eixo estrutural que articulava as dimensôes econômica, política e religiosa. $\mathrm{O}$ nome central da articulação foi o de Arolde de Oliveira, e suas açóes estratégicas formuladas a partir de seu grupo de comunicação (rádio e gravadora) e sua participação na política formal partidária e governamental, citadas anteriormente. Gostaria de me somar a essa discussão acerca das forças políticas e econômicas que sustentam projetos religiosos (tal como discutido por Sant'Ana 2017, Cunha 2004, entre outros), com reflexóes sobre a dimensão estética das práticas políticas e religiosas de Flordelis.

${ }^{21}$ FLORDELIS - A VOLTA POR CIMA (AO VIVO). Publicado pelo canal MK Music [S.I.:s.n.] 2016. 1 video (5:46min). Disponível em https:/www.youtube.com/watch?$\mathrm{v}=5 \mathrm{O} 5 \mathrm{xyt} 51 \mathrm{HPk}$ Acesso em 16 de novembro de 2018 . 
A entrada de Flordelis na política partidária e sua candidatura foram formuladas a partir de práticas estéticas que têm na música seu principal elemento. A dimensão estética é um aspecto importante nas análises acerca das práticas políticas e de governança. Dizem respeito à produção de afetos, sensibilidades e sensorialidades que participam da experiência imersiva da política.

Dedico-me a pensar sobre a dimensão estética tomando por base as ideias de Birgit Meyer relacionadas aos conceitos de mediaçáa $0^{22}$ e estética. Tal como discutido em trabalho anterior sobre a obra de Meyer (Machado, 2015), compreendo a definição de "mediação" nesta autora como algo que se assenta em complexos processos de transmissão que requerem intermediários (meios / mídias). As mídias, tal como entendidas pela autora, não apenas transportam a mensagem de modo neutro, mas lhe dá forma em virtude de suas propriedades e propensôes tecnológicas, sociais e estéticas, através de formatos e formas específicas.

$\mathrm{O}$ ato de mediaçáo, assim compreendido, desperta sensibilidades através de apelos singulares aos órgãos dos sentidos e por carregar significados e valores específicos em sua própria forma (Meyer 2013). O forte interesse no corpo, nos sentidos, na experiência e na estética nas ciências sociais, aponta Meyer, assinala hoje uma crescente consciência de que o surgimento e a manutenção das formaçôes sociais dependem de estilos que formam e vinculam os sujeitos, não apenas através da imaginação cognitiva, mas também através da moldagem dos sentidos e dos corpos em construção (Meyer 2009). Atenta a estas questóes, retomo o material etnográfico sobre Flordelis.

A agenda política de Flordelis se constituiu através de suas produçōes no campo musical, de suas cançôes (letra, melodia e ritmo) e do modo como ela

${ }^{22}$ Apesar de seguir minha análise a partir de referências específicas que me formaram mais diretamente, gostaria de destacar a relevância neste debate do campo de produçóes brasileiras sobre Antropologia das Emoçóes (Rezende e Coelho, 2010) e a antropologia de Gilberto Velho sobre mediação (Velho, 1981; Velho e Kuschnir, 2001).

Debates do NER, Porto Alegre, ano 20, N. 38, P. I9-59, Ago./Dez. 2020 
as performatizava em suas apresentaçôes ao vivo: por isso o entrelaçamento central entre as suas músicas e seus slogans/temas de campanha.

As inúmeras vezes que ouvi Flordelis cantar "A volta por cima" no CIM foram momentos de intensa adesão da audiência, imersa em uma paisagem sonora e visual formada pelo conjunto de corpos e vozes que a acompanhavam, pelos instrumentos, e pelos jogos de luzes que adensavam ainda mais o ambiente. O desejo de "dar a volta por cima" passava também pela experiência afetiva, corporal e sensorial de cantar e dançar girando em torno do próprio corpo dizendo "vai virar, vai virar, vai virar, vai virar. A página da minha história Deus vai virar"23.

Uma abordagem antropológica da paisagem sonora, sobre aquilo que se escuta, é bem mais rara do que leituras sobre a dimensão visual da pesquisa, sobre o que se vê no campo. Dentre os estudos que tratam da relação entre religiáo, mídia e espaço público, destaca-se o trabalho pioneiro e absolutamente inspirador de Hirshckind (2006) sobre o que foi por ele caracterizado como "ethical soundscape", uma paisagem sonora composta por sermóes islâmicos gravados em fita cassete, sua reprodução, circulação, e as práticas religiosas e públicas desenvolvidas a partir desses ${ }^{24}$.

O trabalho de Oosterbaan (2017) adiciona uma análise urbana às leituras sobre paisagens sonoras no campo de estudos de religião e mídia, ao abordar a presença do pentecostalismo nas favelas da cidade do Rio de Janeiro. Baseado em uma pesquisa de longa duração, o autor pensa sobre as disputas internas à vida nas favelas, também em ternos territoriais, articulando tensóes entre projetos de governança com seus "sons" em disputa no cotidiano. O trabalho do autor conjuga uma análise sobre religião, violência e a vida

\footnotetext{
${ }^{23}$ FLORDELIS - A VOLTA POR CIMA (AO VIVO).

${ }^{24}$ Como destaca Stolow (2013), as tecnologias de imagem e áudio, e suas materialidades, como no caso das fitas cassete pesquisadas por Hirschkind, são aspectos imprescindíveis da formação de práticas religiosas. Apenas por serem portáteis como objetos e em sua possibilidade de reprodução, as fitas cassete discutidas por Hirschkind foram centrais à formação de práticas religiosas públicas, tal como analisado por este autor.
}

Debates do NER, Porto Alegre, ano 20, N. 38, P. I9-59, Ago./Dez. 2020 
urbana, sempre com a paisagem sonora em destaque e como fio condutor da análise. O livro de Oosterbaan inclui ainda uma fina discussão acerca das experiências de escuta no pentecostalismo, levando em consideração a importância da música, do rádio, e outros equipamentos eletroacústicos. Ao tratar da escuta musical pentecostal, ele analisa a moralidade do que se deve ou não escutar, do que é bênção, do que é perigo, e as várias dinâmicas operadas pelos sujeitos nessas fronteiras.

A partir do debate produzido por Oosterbaan, podemos identificar a importância da música gospel na vida das periferias urbanas do Rio de Janeiro, e como, através desta vivência sonora, são moduladas moralidades, fronteiras territoriais, pertencimentos e conflitos. A música gospel pode ser então pensada como elemento crucial da estética da política nas periferias, da formação de subjetividades e das disputas em torno de projetos de governança nos territórios.

A voz de Flordelis tem o tom das vozes das cantoras populares brasileiras de forró: uma voz rasgada, na garganta, sem ser burilada no estilo gospel estadunidense, mas que mantém um vibrato popular, um tremor na voz que ora carrega a agonia do clamor presente em suas cançóes, e ora dá o tom da alegria da vida pentecostal em ritmo mais brasileiro. Além de sua voz, Flordelis no CIM canta com um conjunto massivo de vozes que a acompanham. Essa experiência do cantar junto com muitas pessoas promove sensaçóes, vibraçóes corporais, movimentos, aquece o corpo pela produçáo da voz quase aos berros, faz dançar, erguer as mãos, por vezes chorar. Todos estes elementos descrevem vivências mais gerais tanto em shows musicais, quanto em eventos políticos, como também em atos religiosos, tornando inútil qualquer esforço em saber onde começa um e termina o outro.

O CIM 2018, diferente dos anos anteriores em que as candidaturas políticas eram abertamente apresentadas, foi marcado por uma maior discrição quanto à candidatura de Flordelis e de outros políticos a ela relacionados. A eleição de 2018 foi acompanhada por um debate público e junto à justiça eleitoral acerca do que se poderia ou não fazer dentro das igrejas em período de campanha. Discutia-se, à época, iniciativas que propunham o afastamento 
das lideranças de suas funçôes eclesiásticas em período eleitoral. Questionava-se nesse sentido, e com foco específico nos evangélicos, quando o "abuso" do poder religioso virava crime eleitoral. Cogitava-se o uso da "influência" do líder espiritual para "seduzir" seus fiéis e capturar sua liberdade de escolha, os convencendo a aderir a uma certa candidatura. Discutia-se, assim, questóes em torno da pergunta: "onde termina a liberdade religiosa e começa o proselitismo político?” e em que casos o problema deveria ser tratado nesses termos ${ }^{25}$.

Em setembro de 2018 Flordelis já era oficialmente candidata à deputada federal. Por esse mesmo motivo eu fui ao Congresso esperando que naquele ano o espetáculo político fosse o mais ostensivo de todos, e encontrei exatamente o contrário. Em 2016, nas eleiçôes municipais, quase todos os dias havia no palco momentos de explícita articulação e mobilização política para as campanhas em andamento. Em 2017, fora do tempo da eleição ${ }^{26}$, o CIM sediou atos cívicos, com a presença de lideranças políticas celebrando o município, o estado e a nação. Muitos políticos no exercício de seus mandatos compareceram ao evento. Relembre-se aqui o fato de o CIM acontecer frequentemente na semana do feriado nacional de 07 de setembro, o que reforça a dimensão cívica do evento.

Em 2018, no entanto, eu não ouvi nenhuma referência explícita à candidatura de Flordelis durante os cultos em que estive. Alguns convidados externos oravam pela "missão da pastora", para a qual Deus a havia levantado, mesclando um clamor por seu pastorado e por sua conhecida candidatura. Claro que inúmeras referências implícitas circulavam no evento,

${ }^{25}$ BALLOUSSIER, ANNA VIRGINIA. ABUSO DE PODER RELIGIOSO DIVIDE CORTES ELEITORAIS E É CONTESTADO POR PASTORES. Site da Folha de São Paulo [S.I.:s.n.] 2018. Disponível em: https://www1.folha.uol.com.br/poder/2018/06/ abuso-de-poder-religioso-divide-cortes-eleitorais-e-e-contestado-por-pastores.shtml?utm_ source=newsletter\&utm_medium=email\&utm_campaign=newsfolha?loggedpaywall Acesso em 06 de junho de 2018.

${ }^{26}$ Cabe aqui uma referência explícita às reflexôes de Palmeira (apud Peirano, 2002) sobre o "tempo da política". 
mas certamente havia uma mudança no modelo de fazer política eleitoral sendo experimentado naquele ano.

Poucos candidatos em campanha para outros cargos circularam no CIM 2018. Arolde de Oliveira, candidato a Senador e dono da MK Music, esteve presente e ocupou o palco durante breves momentos, durante os quais o Pastor Anderson do Carmo orou por sua vida e por sua missão na proteção da igreja e da família brasileira. Índio da Costa, candidato a governador, foi ao CIM em um dos dias, e apesar de ter sua presença notificada à plateia, náo falou à congregaçáo. Nấo ouvi nenhuma referência explícita à candidatura de Jair Bolsonaro, candidato à presidência apoiado por Arolde de Oliveira e seu partido, incluindo Flordelis.

A campanha de Flordelis só se intensificou após o CIM 2018, e foi composta por dois modelos de intervençáo pública: alguns atos de campanha nas ruas e nas mídias sociais, onde divulgava sua candidatura e suas principais ideias, e muitas idas a igrejas para participaçáo em eventos como cantora gospel. O número de participaçôes em cultos e eventos evangélicos era absolutamente superior às açôes divulgadas em sua agenda de candidata. Por privilegiar a presença em eventos religiosos, Flordelis manejou uma complexa economia moral, política e estética de suas apariçóes como candidata e como cantora ${ }^{27}$.

2019 foi o primeiro ano do mandato como deputada federal de Flordelis. Logo nos seus primeiros meses de atividade, realizou um grande evento no Congresso Nacional denominado "Seminário Cruzada pela adoção: 9 meses,

${ }^{27} \mathrm{O}$ caso de Flordelis não é um fato isolado. Em 2018 a música gospel confirmou-se como um campo privilegiado de formaçáo de carreiras políticas. Se os pastores e bispos eram até então os principais nomes evangélicos na política formal, em 2018 o campo incluiu fortemente o incentivo às carreiras políticas de músicos gospel. Destacaram-se nestas eleiçôes os nomes de Mattos Nascimento (RJ) Samuel Santos (GO), Vanilda Bordieri (SP), Irmão Lázaro (BA), Lauriete (ES), Cristina Mel (RJ), Adriano Gospel Funk (RJ) para citar alguns casos, além de outros mais conhecidos do público brasileiro que também aliam há alguns anos carreiras políticas a carreiras na música gospel, como Marco Feliciano (SP) e Magno Malta (ES)

Debates do NER, Porto Alegre, ano 20, N. 38, P. 19-59, Ago./Dez. 2020 
família para todos". Realizado no mês de maio ("mês das máes"), o Seminário contou com o franco apoio da Ministra Damares Alves, a própria também protagonista de um controverso caso de adoçáo. Flordelis já no início do ano aparecia como um dos nomes cotados para as eleiçóes municipais de 2020, na qual despontava como candidata a prefeita de São Gonçalo. Toda atuação de Flordelis no Congresso Nacional em 2019 era realizada tendo ao lado seu marido o Pastor Anderson do Carmo, seu principal assessor e secretário estadual de seu partido, o PSD.

Mas em junho de 2019, o Pastor Anderson do Carmo foi assassinado dentro de sua residência em Sáo Gonçalo. Em seu corpo foram encontradas 30 perfuraçóes, o que indicava uma quantidade mínima de 15 tiros. O caso teve ampla repercussão midiática e mobilizou muitas polêmicas. Dois filhos do casal foram presos pelo assassinato. As investigaçóes trabalham com a hipótese do envolvimento de Flordelis no crime, e a especulaçáo pública sobre as motivaçóes e as responsabilidades tocam fundamentalmente em questôes de gênero, família, religiáo e sexualidade, pouco se referindo aos conflitos políticos envolvendo Flordelis e Anderson do Carmo.

Em agosto de 2020, durante a finalização da elaboração deste artigo, Flordelis foi indiciada como mandante do assassinato de Anderson do Carmo. A montagem pública do caso mobilizou aspectos da vida familiar de Flordelis, particularmente sua dimensão sexual, indicando possíveis relacionamentos entre filhos, e também entre pais e filhos. Retomou-se o fato de que Anderson, 16 anos mais novo do que Flordelis, havia sido namorado de uma de suas filhas antes de tornar-se seu namorado e marido. A imagem de Flordelis passou a estampar vídeos e memes que a apresentavam como uma "hipócrita defensora da família", "da vida" e "dos bons costumes". Seus posicionamentos morais de cunho religioso, amplamente difundidos em suas mídias sociais nos últimos anos, foram recuperados e acionados como denúncia de sua hipocrisia, quando comparados aos últimos acontecimentos em torno de seu nome, e de sua família. 
Apesar do enorme desgaste público de Flordelis, a deputada e pastora, mesmo sendo investigada pelo assassinato de seu marido, e em meio a muitas reportagens escandalosas sobre sua vida particular, não se esquivou de manter suas redes sociais ativas e apresentar-se publicamente na mídia, divulgando ações de seu Ministério e de seu mandato.

O Ministério Flordelis foi desmantelado nesse processo. Alguns dos filhos do casal desvincularam-se da igreja. Misael "da Flordelis", o filho eleito vereador de São Gonçalo em 2016, afastou-se da mãe adotiva e de seu Ministério, e passou a protagonizar a luta por justiça no caso do assassinato de Anderson do Carmo. Desde o CIM 2019, e em todos os momentos que seguiram os escândalos, o afrouxamento de relaçóes institucionais foi avassalador. Nenhum nome reconhecido do campo evangélico pentecostal esteve presente no Congresso de 2019. O PSD, partido de Flordelis, agiu rápido ao suspender a filiaçáo da deputada e iniciar seu processo de expulsão. A MK Music rompeu o contrato que tinha com a cantora há mais de uma década. Arolde de Oliveira ${ }^{28}$, senador eleito, dono da MK Music e articulador da candidatura de Deputada Federal pelo PSD, formalizou seu afastamento. Um deputado federal do PSL apresentou representaçáo à Mesa da Câmara dos Deputados para que fosse encaminhado ao Conselho de Ética pedido de perda de mandato da deputada por quebra de decoro parlamentar. Damares Alves que se aproximou de Flordelis pela pauta da adoçáo no início de seu mandato em 2019, veio a público ao lado do presidente Jair Bolsonaro em uma de suas lives dizer que a pastora "enganou topo do país", e lamentou que estes escândalos em torno do caso possam afetar a pauta da adoção. Bolsonaro disse que as fotos de Flordelis ao seu lado e de sua esposa Michelle estavam sendo usadas para "desgastá-lo".

Retomando as reflexôes sobre o tempo da política, vale relembrar que Flordelis foi indiciada em ano de eleiçôes municipais (2020). Como dito

${ }^{28}$ O Senador Arolde Oliveira faleceu em 21 de outubro de 2020, aos 83 anos, vítima da COVID-19. 
anteriormente, Anderson do Carmo e sua esposa eram parte do campo político que se apresentava à prefeitura de São Gonçalo.

Olham para mim, já julgando o meu final Esquecendo que o meu Deus, é um Deus sobrenatural O Deus que dá valor, a quem o mundo humilhou É o Deus que uma virada em minha vida decretou As vezes a gente erra, tentando acertar E o nosso nome vira o alvo, de quem quer acusar Mesmo machucados, temos que continuar Quem obedece aqui em baixo, amanhã por cima vai estar

Dar "a volta por cima” tornou-se então um projeto pessoal para Flordelis. Não mais apenas um testemunho sobre sua história. Também não apenas uma mensagem para os que a ouvem como pastora ou deputada. A partir do escândalo da morte de Anderson do Carmo, ela própria encarnou o suplício de redefinir sua história.

O pentecostalismo das periferias urbanas se constituiu como um campo de quedas e retornos, escândalos e glórias, derrotas e vitórias, e em meio a isso, de muitas lutas e provaçóes. É um pentecostalismo que habita as cadeias, as delegacias, as ruas, as bocas de fumo, e assume que é lá, onde mora o "pecado", que se deve oferecer um projeto de redenção. "Onde abundou o pecado, superabundou a graça” (Romanos 5:20). Atravessar o tempo do suplício aguardando o tempo da vitória é parte das possibilidades do campo pentecostal, assim como o tempo da redenção, mesmo quando confirmado o pecado ou o crime, e seu veredicto. A justiça dos homens e a justiça de Deus operam lado a lado, mas não necessariamente juntas. $\mathrm{Na}$ moralidade pentecostal, mesmo o caído pode se levantar pela graça.

Escândalos, quedas, acusações, processos e prisóes não são fenômenos exclusivos do campo político pentecostal. O tempo do suplício é um dos tempos da política, e tanto o suplício, quanto os processos de redenção política que o seguem, são compostos por complexas operaçóes morais 
com componentes religiosos e seculares. Durante os mesmos anos do CIM, acompanhamos em rede nacional muitos processos de suplício político. As crises alternam seus envolvidos. Enquanto alguns campos políticos vivem suas crises, outros se fortalecem. A igreja de Flordelis esteve de pé em tempos de outras crises, de 2016 a 2019. Agora ela vivencia sua própria crise, perde os apoios que a ergueram e sustentaram outrora, e cai. Pode-se dizer que o tempo da política nestes anos foi marcado por tempos de suplício religiosos e seculares. E o caso de Flordelis não foi um caso isolado.

Durante a pesquisa de campo na ADUD e no Ministério Flordelis presenciei atores do campo político evangélico atravessarem grandes escândalos mantendo presença constante em eventos públicos, e também aqueles que desapareceram. O modo de fazer política pentecostal, e a música gospel que faz vibrar suas agendas, operam com a possibilidade de se dar a volta por cima, de haver a restituição, redenção. Mas, cabe sempre lembrar, essas possibilidades podem se confirmar, ou não. Pesquisas situadas, que assumem a dimensão temporal e processual da vida social, mobilizam relaçóes sociais que passam por mudanças, continuidades, rupturas, surgimentos e desaparecimentos. E essa radicalidade da ação do tempo é presente não apenas na pesquisa, mas na vida cotidiana, ordinária, e em sua própria radicalidade. Na vida das periferias, a "queda" é parte do cotidiano, e uma religião que abarque suas demandas precisa se deixar permear por essas dinâmicas, esses fluxos, essas tramas, com seus ritmos descompassados e melodias polifônicas.

\section{CONSIDERAÇÕES FINAIS}

Os estudos que partem da questão da relação entre religião e mídia possibilitam desdobramentos muito variados. Este artigo teve por objetivo desenvolver dois aspectos oportunizados por este enfoque: primeiramente, uma análise de modos de formação e ação política no meio pentecostal. Ministérios e Congressos foram categorias condutoras da reflexão aqui apresentada. Através de um ministério - o Ministério Flordelis - foi possível 
analisar um tipo de formação político-religiosa que tem por característica central desafiar modos de organização espaço-temporal. Ministérios se propóem a ocupar não apenas templos (e podem mesmo prescindir de templos), mas ruas, cidades, e outros tantos domínios digitais. Apresentam-se sob a forma de eventos, operam importantes aparatos midiáticos, voltando-se, assim, ao espaço expansivo mobilizado por suas missões, seus projetos. E seus projetos, como tais, apontam para o futuro: ao tempo da mudança, da transformação, dos processos. Suas alianças são assim dinâmicas, fluidas, instáveis e muitas vezes frágeis.

Tomando um congresso como campo de pesquisa - o Congresso Internacional de Missôes (CIM) - busquei uma abordagem que tornasse viável concentrar esforços analíticos para capturar um Ministério em ação, no ato de sua expansão espaço-temporal, e na execução de seus processos de formação de redes interescalares. Acompanhar este congresso por alguns anos evidenciou ainda seu aspecto dinâmico, instável, e trouxe a compreensáo sobre como se processam, no âmbito destes eventos que se repetem sempre se reinventando, tempos de fortalecimento, vitória, esmaecimento, suplício e tormento.

O outro aspecto discutido neste artigo, a partir da relação entre religião e mídia, foi a estética da política do campo pentecostal que se constitui a partir da música gospel. Tratar da estética da política significa abordar processos sensoriais, perceptivos, corporais, afetivos, narrativos, e o modo como estes participam da produção de processos de legitimação e práticas autorizativas de um certo campo político e religioso pentecostal.

Como contribuição aos estudos de religião e mídia, reforço a importância de abordarmos as questóes desse campo a partir de estudos situados, e particularmente a partir das periferias urbanas, e da política que se faz nas e a partir das periferias. Uma abordagem da articulação entre projetos religiosos e produçóes midiáticas, com questóes que se colocam a partir de regimes territoriais e práticas de governança nas periferias urbanas, mobiliza uma inscrição potente para discussóes sobre o Brasil contemporâneo e seus processos de continuidades e rupturas políticas. É fundamental, ainda, e 
por isso, integrar cada vez mais o debate sobre religiáo, mídias e mediaçôes, éticas e estéticas, às discussōes sobre projetos de poder, e suas dimensōes políticas, econômicas e culturais.

E onde há poderes, há conflitos e crises. Pensando as articulaçóes do religioso e do secular nos tempos da política, sugiro seguirmos refletindo sobre o tempo do suplício nas modulações das crises da política nacional brasileira. Sobre os tempos da queda e da redenção, do escândalo e da vitória, da relação entre blasfêmia e verdade no emaranhado político e religioso que faz a política brasileira há séculos, e a partir do qual se formula o secular no Brasil.

São muitas as metáforas que usamos nas Ciências Sociais para expressar nossos modos de pensar. As ideias de "tramas" e "emaranhados", que tanto utilizamos no grupo de pesquisa Distúrbio (UERJ), são uma forma de provocar pesquisas que assumam os imbricamentos próprios à vida ordinária, e estranhem as leituras mais rígidas na circunscrição de esferas da vida social, e sua abordagem. Pensar em tramas é um convite ao "entranhamento", e ao desafio de se mobilizar teorias e metodologias para esta abordagem emaranhada, mesmo correndo riscos de profanar fronteiras. Espero neste artigo náo haver apresentado soluçôes para o contínuo desafio antropológico, mas ter feito um exercício produtivo e bom para o diálogo.

\section{REFERÊNCIAS}

ASAD, Talal. Genealogies of Religion: Discipline and Reasons of Power. In: Christianity and Islam. Baltimore and London: The Johns Hopkins University Press. 1993.

ASAD, Talal. Formations of the Secular: Christianity, Islam, Modernity. California. Stanford University Press. 2003.

BANDEIRA, Olívia. Música gospel no Brasil: reflexóes em torno da bibliografia sobre o tema. Religiäo \& Sociedade, v. 37, n. 2, 2017, pp. 200-28. 
BEZERRA, Jamille. Profetizando às Mulheres: mídia gospel, gênero e politica. 2018. Dissertação. (Mestrado em Ciências Sociais) - Universidade Federal Rural do Rio de Janeiro, Rio de Janeiro. 2018.

BIRMAN, Patricia. Cruzadas pela paz: práticas religiosas e projetos seculares relacionados à questão da violência no Rio de Janeiro. Religião \& Sociedade, 32(1), 2012, pp. 209-226.

BIRMAN, Patricia. Mediação feminina e identidades pentecostais. Cadernos Рagu (6-7), 1996, pp.201-226.

BIRMAN, Patrícia. Narrativas seculares e religiosas sobre a violência: as fronteiras do humano no governo dos pobres. Sociologia \& Antropologia, 9(1), 2019, pp. 111-134.

BIRMAN, Patricia (org). Religião e espaço público. São Paulo: Attar Editorial. 2003.

BIRMAN, Patricia; MACHADO, Carly. A violência dos justos: evangélicos, mídia e periferias da metrópole. Revista Brasileira de Ciências Sociais, vol. 27, núm. 80, octubre, 2012, pp. 55-69.

BURDICK, John. Pentecostalismo e identidade negra no Brasil. Mistura possível? In: MAGGIE, Yvonne e REZENDE, Claudia (orgs). Raça como retórica: a construção da diferença. Rio de Janeiro: Civilização Brasileira. 2002. BURITY, Joanildo. Minoritization and Pluralization. What Is the "People" That Pentecostal Politicization Is Building? LATIN AMERICAN PERSPECTIVES, Issue 208, Vol. 43 No. 3, 2016, pp. 116-132.

CHAVES, Christine. A Marcha Nacional dos Sem-Terra: um estudo sobre a fabricaçâo do social. Rio de Janeiro: Reluma Dumará/NUAP. 2000.

CHAVES, Christine. Festas da politica: uma etnografia da modernidade no sertão (Buritis/MG). Rio de Janeiro: Reluma Dumará/NUAP. 2003. 
CONTINS, Marcia. Subjetividade e alteridade: os pentecostais negros no Brasil e nos Estados Unidos. LOGOS 21: Comunicação e religiosidades. Ano 11, n$^{\circ} 21,2^{\circ}$ semestre de 2004, pp. 151-174.

CUNHA, Christina. Oração de traficante: uma etnografia. Rio de Janeiro: Garamond. 2015.

CUNHA, Magali. "Vinho novo em odres velhos": um olhar comunicacional sobre a explosáo gospel no cenário religioso evangélico no Brasil. Tese (doutorado em comunicação), São Paulo, Universidade de São Paulo, 2004.

D’ANDREA, Tiarajú Pablo. A formação dos sujeitos periféricos: cultura e política na periferia de São Paulo. Tese (doutorado em sociologia), São Paulo, Universidade de São Paulo, 2013.

DULLO, Eduardo (prelo). A Political Ritual Without Closure: Serial Liminality and the Escalation of Conflict in Brazil's Street Demonstrations.

FELDMAN-BIANCO, Bela (org). Antropologia das sociedades contemporâneas: métodos. São Paulo. Editora UNIFESP, 2010.

FRESTON, Paul. Brother votes for brother: the new politics of Protestantism in Brazil. In: STOLL, David, GARRARD-BURNETT, Virginia (eds.), Rethinking Protestantism in Latin America. Philadelphia: Temple University Press. 1993.

GALDEANO, Ana Paula. A gestão social da violência: de como ativistas de direitos humanos, líderes de associação de bairro e evangélicos se mobilizam. In: CUNHA e FELTRAN (org). Sobre periferias: novos conflitos no Brasil contemporâneo. Rio de Janeiro: Lamparina \& FAPERJ. 2013.

HIRSCHKIND, Charles. The Ethical Soundscape: Cassette Sermons and Islamic Counterpublics. Nova York: Columbia University Press, 2006.

HIRSCHKIND, Charles. Existe um corpo secular? Religião \& Sociedade, v. 37, n. 1, 2017, pp. 175-89. 
JUNGBLUT, Airton Luiz. A salvação pelo rock: sobre a 'cena underground' dos jovens evangélicos no Brasil. Religiāo \& Sociedade, v. 27, n. 2, 2007, pp. 144-62.

MACHADO, Carly. Conexôes e rupturas urbanas: projetos, populaçôes e territórios em disputa. Revista Brasileira de Ciências Sociais, 32(93), e329308. 2017 a.

MACHADO, Carly. "É muita mistura": projetos religiosos, políticos, sociais, midiáticos, de saúde e segurança pública nas periferias do Rio de Janeiro. Religiâo \& Sociedade, 33(2), 2013, pp. 13-36.

MACHADO, Carly. Pentecostalismo e o sofrimento do (ex-)bandido: testemunhos, mediaçôes, modos de subjetivação e projetos de cidadania nas periferias. Horizontes Antropológicos, n. 42, 2014, pp. 153-80.

MACHADO, Carly. Religião e Mídia: reflexões de uma mente inquieta e o desafio de uma antropologia "sensacional". Campos 16(2), 2015, pp.138-144.

MACHADO, Carly. Samba gospel: Sobre pentecostalismo, cultura, política e práticas de mediação nas periferias urbanas do Rio de Janeiro. Novos estudos CEBRAP, 39(1), 2020, pp. 81-101.

MACHADO, Carly. The church helps the UPP, the UPP helps the church: pacification apparatus, religion and boundary formation in Rio de Janeiro's urban peripheries. Vibrant: Virtual Brazilian Anthropology, 14(3), e143075. 2017b.

MACHADO, Maria das Dores Campos. Política e Religião: a participação dos evangélicos nas eleiçôes. Rio de Janeiro: Editora FGV. 2006.

MACHADO, Maria das Dores Campos. Representaçóes e relaçóes de gênero nos grupos pentecostais. Revista Estudos Feministas, 13(2), 2005, pp. 387-396. MAFRA, Clara; ALMEIDA, Ronaldo de (orgs.). Religióes e cidades: Rio de Janeiro e São Paulo. São Paulo: Terceiro Nome, 2009. 
MARIZ, Cecília. A teologia da batalha espiritual: uma revisão da bibliografia. $B I B$, n. 47, 1999, pp. 33-48.

MAURICIO JUNIOR, Cleonardo. 'Acordamos, Somos Cidadãos': os evangélicos e a constituição ética de si na relação com o político. Revista ANTHROPOLÓGICAS. Ano 23, 30(1), 2019, pp. 99-135.

MEINERT, Lotte; KAPFERER, Bruce (edit). In the event: toward an anthropology of generic moments. New York; Oxford. Ed. Berghahn. 2015.

MESQUITA, Wania. Religiosidade pentecostal e ordem violenta em favelas na cidade de Campos dos Goytacazes. In: CUNHA e FELTRAN (org). Sobre periferias: novos conflitos no Brasil contemporâneo. Rio de Janeiro: Lamparina \& FAPERJ. 2013.

MEYER, Birgit; MOORS, Annelies (eds.). Religion, media and the public sphere. Bloomington/Indianapolis, Indiana University Press. 2006.

MEYER, Birgit; PELS, Peter (eds.). Magic and modernity: interfaces of revelation and concealment. Stanford, Stanford University Press. 2003.

MEYER, Birgit. Aesthetic formations: media, religion, and the senses. Nova York, Pal-grave Macmillan. 2009.

MEYER, Birgit. "Material Mediations and Religious Practices of World-making". In: K. Lundby (Eds.), Religion Across Media: From Early Antiquity to Late Modernity. New York: Peter Lang International Academic Publishers, 2013, pp. 1-19.

NOVAES, Regina. Juventude, religião e espaço público: exemplos 'bons para pensar' tempos e sinais. Religião \& Sociedade, v. 32, n. 1, 2012, pp. 184-208. OOSTERBAAN, Martijn. Gospel Funk: Pentecostalism, Music, and Popular Culture in Rio de Janeiro. In: INGALLS, Monique; YONG, Amos (orgs.). The Spirit of Praise: Music and Worship in Global Pentecostal-Charismatic Christianity. University Park: Penn State University Press. 2015. 
OOSTERBAAN, Martijn. Transmitting the spirit: religious conversion, media, and the urban in Brazil. University Park, Pennsylvania: The Pennsylvania State University Press. 2017.

Paula, Robson de. "Os cantores do Senhor": três trajetórias em um processo de industrialização da música evangélica no Brasil. Religião \& Sociedade, v. 27, n. 2, 2007, pp. 55-84.

PAZ, Sthefanye. Tonzão entre dois "mundos": mediaçôes e agência entre o funk e a igreja. Dissertaçáo. (Mestrado em Ciências Sociais) - Universidade Federal Rural do Rio de Janeiro, Rio de Janeiro, 2018.

PEIRANO, Mariza (org.). O dito e o feito: ensaios de antropologia dos rituais. Rio de Janeiro: Relume Dumará. 2002.

PINHEIRO, Márcia Leitão. Música, religião e cor: uma leitura da produção de black music gospel. Religiäo \& Sociedade, v. 27, n. 2, 2007, pp. 163-80. PINHEIRO, Márcia Leitão; FARIAS, Carine Lavrador de. O funk abençoado: apropriaçấo musical, trajetória religiosa e carreira musical de MC Polliana Gospel Funk. Religião \& Sociedade, v. 39, n. 3, 2019, pp. 34-57.

PINHO, Osmundo de Araújo. A vida em que vivemos: raça, gênero e modernidade em São Gonçalo. Rev. Estud. Fem., Florianópolis, v. 14, n. 1, 2006, pp. 169-198.

REINA, Morgane. Pentecostalismo e a questão racial no Brasil: desafios e possibilidades de ser negro na igreja evangélica. PLURAL, Revista do Programa de Pós-Graduação em Sociologia da USP, São Paulo, v.24.2, 2017, pp.253-275.

REVEL, Jacques (org). Jogos de escalas: a experiência da microanálise. Rio de Janeiro: Fundação Getúlio Vargas. 1996.

REZENDE, Claudia Barcellos e COELHO, Maria Cláudia. Antropologia das Emoçôes. Rio de Janeiro: Editora Fundação Getúlio Vargas. Série Sociedade e Cultura, 2010. 
ROSAS, Nina. "Amostra grátis" da prosperidade: açóes de assistência na Igreja Universal e o caso de Minas Gerais. In: CUNHA e FELTRAN (org). Sobre periferias: novos conflitos no Brasil contemporâneo. Rio de Janeiro: Lamparina \& FAPERJ. 2013.

SANT'ANA, Raquel. A música gospel e os usos da 'arma da cultura': reflexôes sobre as implicaçóes de uma emenda. Intratextos, v. 5, n. 1, 2013, pp. 23-41. SANT'ANA, Raquel. A Nação cujo Deus é o Senhor: a imaginação de uma coletividade "evangélica" a partir da Marcha para Jesus. Tese (doutorado em antropologia social), Museu Nacional, Universidade Federal do Rio de Janeiro, Rio de Janeiro, 2017.

SCHELIGA, Eva. Educando sentidos, orientando uma práxis - etnografia das práticas assistenciais de evangélicos brasileiros. Tese (Doutorado em Antropologia) - Universidade de São Paulo, São Paulo, 2011.

STOLOW, Jeremy. Deus in Machina: religion, technology, and the things in between. New York: Fordham University Press. 2013.

TEIXEIRA, Carla; CHAVES, Christine (org). Espaços e tempos da politica. Rio de Janeiro: Relume Dumará/NUAP UFRJ. 2004.

TEIXEIRA, Cesar Pinheiro. A construção social do ex-bandido: um estudo sobre sujeição criminal e pentecostalismo. Rio de Janeiro: Letras, 2011.

TEIXEIRA, Cesar. Saindo do crime: igrejas pentecostais, ONGs e os significados da ressocialização. In: BIRMAN; LEITE; MACHADO e CARNEIRO (org). Dispositivos urbanos e trama dos viventes: ordens e resistências. Rio de Janeiro: Editora FGV. 2015.

TEIXEIRA, Jacqueline Moraes. A mulher Universal: corpo, gênero e pedagogia da prosperidade. Rio de Janeiro: Mar de Idéias. 2016.

VAINER, Carlos. Lugar, região, Nação, mundo. Exploraçôes históricas do debate acerca das escalas da ação política. $R$. B. Estudos urbanos e regionais v. 8, n. 2, 2006, pp.9-29. 
VELHO, Gilberto. Individualismo e Cultura: notas para uma antropologia da sociedade contemporânea. Rio de Janeiro, Jorge Zahar. 1981.

VELHO, Gilberto e KUSCHNIR, Karina (orgs.). Mediação, Cultura e Política. Rio de Janeiro: Aeroplano. 2001.

Recebido em: 31/08/2020

Aprovado em: 31/08/2020

Debates do NER, Porto Alegre, ano 20, N. 38, P. I9-59, Ago./DeZ. 2020 

COMENTÁRIOS 
